\title{
Editorial: special issue "Palaeobiology and Fossil Lagerstätten: a tribute and memorial to Adolf Seilacher"
}

\author{
Joachim Reitner ${ }^{1} \cdot$ Qun Yang $^{2} \cdot$ Yongdong Wang ${ }^{2} \cdot$ Mike Reich $^{3,4}$
}

(C) Paläontologische Gesellschaft 2016

The present special issue of PalZ - Paläontologische Zeitschrift contains articles on the topic of 'Palaeobiology and Geobiology of Fossil Lagerstätten through Earth History' mostly related to presentations at the joint conference of the Paläontologische Gesellschaft and the Palaeontological Society of China that took place at the Georg-August University Göttingen in September 2013 (Reich and Reitner 2013; Reich et al. 2013; Reitner et al. 2013) or to the conference patron by that time - Adolf Seilacher (Seilacher 2013a, b).

Seilacher, who was a professor at Göttingen University between 1963 and 1965, published trend-setting papers on palaeobiology and introduced the today common term (Fossil) Lagerstätten for deposits with exceptionally preserved fossils. Unfortunately, he passed away recently

Mike Reich

m.reich@1rz.uni-muenchen.de; mike.reich@1mu.de

Joachim Reitner

jreitne@gwdg.de

Qun Yang

qunyang@nigpas.ac.cn

Yongdong Wang

ydwang@nigpas.ac.cn

1 Department of Geobiology, Georg-August University Göttingen, Goldschmidtstr. 3, 37077 Göttingen, Germany

2 Nanjing Institute of Geology and Palaeontology, Chinese Academy of Sciences, 39 East Beijing Road, Nanjing 210008, People's Republic of China

3 SNSB - Bavarian State Collection for Palaeontology and Geology, Richard-Wagner-Str. 10, 80333 Munich, Germany

4 Department of Earth- and Environmental Sciences, LudwigMaximilians-Universität München, Richard-Wagner-Str. 10, 80333 Munich, Germany (e.g., Briggs 2014; Hagdorn 2014; Reitner this issue; Reitner and Reich 2014), and for this reason the present issue also is dedicated to him.

\section{References}

Briggs, D.E.G. 2014. Adolf Seilacher (1925-2014). Nature 509(7501): 428

Hagdorn, H. 2014. Adolf Seilacher 1925-2014. Jahreshefte der Gesellschaft für Naturkunde 170(1): 451-472.

Reich, M., and J. Reitner. 2013. Gemeinsame internationale Tagung der Paläontologischen Gesellschaft und der Palaeontological Society of China in Göttingen. GMit. Geowissenschaftliche Mitteilungen 54: 79-80.

Reich, M., J. Reitner, Qun Yang, Yongdong Wang, and M. Gudo. 2013. Nachwuchspreise der Paläontologischen Gesellschaft vergeben. GMit. Geowissenschaftliche Mitteilungen 54: 80-81.

Reitner, J., Qun Yang, Yongdong Wang, and M. Reich. 2013. Palaeobiology and Geobiology of Fossil Lagerstätten through Earth History. A Joint Conference of the "Paläontologische Gesellschaft" and the "Palaeontological Society of China", Göttingen, Germany, September 23-27, 2013. Göttingen: Universitätsverlag: 1-217.

Reitner, J., and M. Reich. 2014. Adolf Seilacher 1925-2014. GMit. Geowissenschaftliche Mitteilungen 57: 83.

Seilacher, A. 2013a. Welcome address. In: Palaeobiology and Geobiology of Fossil Lagerstätten through Earth History. A Joint Conference of the "Paläontologische Gesellschaft" and the "Palaeontological Society of China", Göttingen, Germany, September 23-27, 2013, eds. J. Reitner, Yang Qun, Wang Yongdong, and M. Reich. Göttingen: Universitätsverlag: 11.

Seilacher, A. 2013b. Grußwort. In: Palaeobiology and Geobiology of Fossil Lagerstätten through Earth History. A Joint Conference of the "Paläontologische Gesellschaft" and the "Palaeontological Society of China”, Göttingen, Germany, September 23-27, 2013, eds. J. Reitner, Yang Qun, Wang Yongdong, and M. Reich. Göttingen: Universitätsverlag: 12. 